\title{
RE-ELECTION FOR TRIAL AT PRELIMINARY INQUIRY: $R$. v. Davies
}

SHELLEY L. MILLER*

The right of an accused person, who has elected pursuant to Sections 464 or 484 of the Criminal Code to be tried by a judge with a jury or a judge without a jury, to re-elect to be tried by a magistrate without a jury at any time before his committal for trial was apparently well settled until the

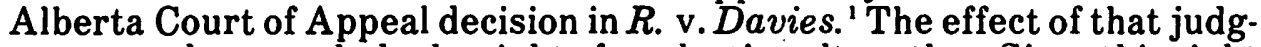
ment may be to exclude the right of re-election altogether. Since this right is a matter of considerable practical importance, the reasoning in Davies merits critical analysis. The statutory provisions of the Criminal Code affecting this right of re-election and the judicial authority leading up to Davies will be examined and analyzed.

\section{STATUTORY PROVISIONS}

The right to elect and re-elect are matters governed by Part XV and Part XVI of the Criminal Code. The sections contained in these Parts deal with procedure on a preliminary inquiry. The right of an accused to elect his mode of trial is protected by the mandatory provisions of subsections $464(2)$ and $484(2)$. Subsections $464(4)$ and $484(3)$ relate specifically to the matter of election at the time of the preliminary inquiry where an accused has elected not to be tried by a magistrate. These sections appear as follows:

Section 464:

(4) Where an accused does not elect to be tried by a magistrate, the justice shall hold a preliminary inquiry into the charge and if the accused is committed for trial or, where the accused is a corporation, is ordered to stand trial, the justice shall

(a) endorse on the information a statement showing the nature of the election or that the accused did not elect, and

(b) state in the warrant of committal, if any, that the accused

(i) elected to be tried by a judge without a jury,

(ii) elected to be tried by a court composed of a judge and jury, or

(iii) did not elect.

\section{Section 484:}

(3) Where an accused does not elect to be tried by a magistrate, the magistrate shall hold a preliminary inquiry in accordance with Part XV, and if the accused is committed for trial or, in the case of a corporation is ordered to stand trial, the magistrate shall

(a) endorse on the information a statement showing the nature of the election or that the accused did not elect, and

(b) state in the warrant of committal, if any, that the accused

(i) elected to be tried by a judge without a jury,

(ii) elected to be tried by a court composed of a judge and jury, or

(iii) did not elect.

These are the only statutory provisions dealing with the power of a magistrate in relation to an election at a preliminary inquiry. There are no express provisions relating to the right to re-elect after an initial election has been made and before committal for trial. There is, therefore, no ex-

* LL.B. (Alta). With the firm of Wachowich and Company.

1. [1979] 6 W.W.R. 1, 16 A.R. 426. 
press statutory power enacted by Parliament to give a magistrate jurisdiction to allow an accused person to re-elect after he has been put to his election as required by the provisions of the Criminal Code. The case law must then be examined to determine whether, in the absence of an expressly legislated power, there exists the jurisdiction in a magistrate to allow a re-election once the initial election is made.

\section{JUDICIAL AUTHORITY}

The first significant case to consider the jurisdiction of a magistrate to hear an application (during a preliminary inquiry) to re-elect to be tried by magistrate was $R$. v. Scown. ${ }^{2}$ The application was brought after the Crown had led most of its evidence and while the presiding magistrate objected to the procedure, he felt himself obliged to grant the application. It should be noted that after the application was granted, the Crown agreed that the evidence led on the preliminary inquiry should apply to the trial.

Upon appeal by the Crown, the Alberta Supreme Court Appellate Division ruled that the accused had no right to re-elect once the preliminary inquiry had commenced. Chief Justice Harvey (Ford and MacDonald JJ.A. concurring) stated: ${ }^{3}$

... there is no provision whatever for a Magistrate having started on a preliminary inquiry thereafter abandoning it and leaving it up in the air. It is his clear duty to carry it to the conclusion specified in the sections of the Code by either dismissing the charge or committing the accused for trial.

There being no authority whatever for the practice adopted and it being against the clear intention of the procedure laid down, the magistrate was wrong in abandoning the preliminary inquiry and had no jurisdicton then to take on a trial, and such being the case, the conviction which followed was made without jurisdiction and must be set aside.

The ruling of the Court was that there was no jurisdiction in the magistrate afforded by the express provisions of the Criminal Code to convert a preliminary inquiry into a trial and that such a practice was against the intent of the statutory procedure. It was held that to allow such applications would result in unfairness to the magistrate by requiring him to reconsider evidence already heard and would promote unnecessary gamesmanship in the criminal process. Furthermore, the Court observed that such a finding would overlook the magistrate's overriding discretion not to adjudicate pursuant to Section 784 (now Section 485) of the Criminal Code.

A similar view was adopted by the Saskatchewan Court of Appeal in $R$. v. Siniaski ${ }^{4}$ In that case, the accused had elected trial by judge without a jury. On the date set for preliminary inquiry, he applied to re-elect to be tried by a magistrate, and immediately upon the granting of his application, he entered a plea of guilty. He appealed his conviction.

Mr. Justice Culliton, on behalf of the Court of Appeal, held that unless the initial election made by the accused was shown to be invalid, such that there was in law no election and therefore the accused would still be entitled to a proper election under Section 468 (now Section 484), the magistrate had no jurisdiction to accept a re-election.

In the same year that Siniaski was decided, the Ontario Court of Appeal considered the issue and arrived at a different conclusion. In $R$. v.

2. [1945] 4 D.L.R. 202, 84 C.C.C. 277, 1 W.W.R. 686.

3. Id. at 283 C.C.C..

4. (1966) 63 W.W.R. 52 . 
Fairbairm ${ }^{5}$ the accused, who had initially elected trial by judge and jury, re-elected to be tried by magistrate on the date of the preliminary inquiry. Aylesworth J.A., delivering judgment for the Court, ruled that there was nothing in Section 468 (now Section 484) which would preclude such a reelection before the preliminary inquiry had been launched. All that had been done in the matter had been the fixing of a trial date. The Court noted that the Crown had consented to the application. Finally, the Court stated that to quash the conviction in all the circumstances would be a travesty of justice.

The Ontario Court of Appeal, although differently constituted, again considered the issue in $R$. v. Cooper ${ }^{6}$ and came to the same conclusion reached in $R$. v. Fairbairn. ${ }^{7}$ In this case, the accused applied to re-elect in the middle of the preliminary inquiry for the purpose of pleading guilty. He was permitted to do so, but then appealed his conviction.

The majority judgment of the Court of Appeal was delivered by MacKay J.A. (McLennan J.A. concurring), who expressed the view that while the Criminal Code did not specifically provide for re-election and the entry of a guilty plea during a preliminary inquiry, neither was such a procedure prohibited. MacKay J.A. stated that the Code was not exhaustive on all matters of procedure and, in support of this proposition, cited the rights of the accused to change his plea during a trial from not guilty to guilty and to change a plea of guilty, before sentence, to not guilty.

The Court pointed to the great expense and inconvenience which would result to all parties concerned and.stated that an injustice to the accused would result if it were held that a preliminary inquiry, once embarked upon, must be taken to its conclusion despite the desire of the defence to admit the charge. The majority judgment found support for its conclusion in the principle stated in the reasons for judgment of Fitzpatrick C.J.C. in the decision of Giroux v. The King.

The majority gave consideration to its earlier decision in $R$. v. Fairbairn and ruled that the comment of Aylesworth J.A., which suggested that a magistrate could permit an accused to re-elect trial by magistrate before any irrevocable step with respect to the preliminary inquiry had been taken, was obiter dicta. The true rule was that the jurisdiction of a magistrate to permit a re-election existed until the accused had been committed for trial, and his discretion might be exercised to allow a reelection any time prior to committal.

In a dissenting opinion, Laskin J.A. (as he then was) was of the view that a magistrate had no jurisdiction to permit a re-election during preliminary inquiry. He stated that if expediency and economy were the justification for the ruling of the majority, such ends could be attained by simply aborting the preliminary inquiry and recommencing on a fresh information. He pointed out that the jurisdiction of a magistrate to permit a re-election could not be based upon an anticipated plea of guilty, since a plea cannot be taken until a re-election is made. Laskin J.A. was of the view that the provisions of the Criminal Code allowed the magistrate the

5. [1967] 1 C.C.C.76.

6. [1968] 2 C.C.C. 104, affd. [1968] S.C.R. 450, [1968] 4 C.C.C. 128, 3 C.R.N.S. 376.

7. Supra n. 5 .

8. (1917) 56 S.C.R. 63 at 67. 39 D.L.R. 190, 29 C.C.C. 258. 
alternatives of proceeding to trial or proceeding to preliminary inquiry. Once he embarked upon one statutory procedure he could not shift to the other without express statutory authority. Laskin J.A. explained the result in Fairbairn on the ground that the magistrate had not yet adopted a statutory course when the application was made; thus it seems that Laskin J. A. would have held that before the preliminary inquiry commenced, a re-election could be permitted.

It is submitted that the majority view, that the timing of the application is irrelevant so long as it is made before committal, is preferable to the dissenting view that a magistrate may hear an application to re-elect only before the preliminary inquiry is launched. The latter distinction is artificial and cannot take account of the evidence which may be led to satisfy the accused that the charge will be established. On the one hand it seems logical to conclude that if a magistrate is found to have jurisdiction at all, such jurisdiction should exist until it is expressly terminated by the committal for trial. This jurisdiction should encompass all matters over which a magistrate has a jurisdiction conferred by law, and there does not logically appear to be a difference between an election, over which a magistrate expressly has authority, and a re-election, about which there is no mention. On the other hand, the view of Laskin J.A. that a guilty plea is an irrelevant consideration to the jurisdiction of a magistrate to permit a re-election also accords with logic.

The majority judgment in Cooper was affirmed without reasons by a five man bench of the Supreme Court of Canada, thereby establishing the following principle of law: a magistrate has jurisdiction to allow an accused person to re-elect to be tried by magistrate and to plead guilty during a preliminary inquiry. Such jurisdiction exists from the time of the initial election by the accused until his committal for trial.

Still unresolved remained the question of whether the consent of the Crown is relevant to an application to re-elect where the accused does not intend to enter a guilty plea. This issue was considered peripherally in British Columbia in two decisions rendered after the decision in Cooper was affirmed by the Supreme Court of Canada.

The first of these decisions was $R$. v. Cross. ${ }^{9}$ There, the Crown opposed the application to re-elect during the course of a preliminary inquiry on the basis that an amendment to the Criminal Code subsequent to the Cooper decision altered the effect of that decision by expressly providing that a re-election could not be sought without the consent in writing of the Crown. Section $474 \mathrm{~A}^{10}$ (now Section 491 ) was the section referred to. Hinkson J. of the British Columbia Supreme Court rejected the submission of the Crown and held that the provisions of Section 474A did not apply at all until after a committal for trial.

In the decision of $R$. v. MacRitchie, ${ }^{11}$ the British Columbia Court of Appeal voiced agreement with the ruling in Cross. Here the accused applied to re-elect on the date set for preliminary inquiry and indicated his wish to plead not guilty. The Crown opposed the application and the provincial judge ruled that he had no jurisdiction to allow the accused to re-elect and plead not guilty. On appeal, the Crown again argued that by virtue of the

9. (1971) 1 C.C.C. (2d) 337.

10. Criminal Law Amendment Act, S.C. 1968-69, c. 38, s. 38.

11. [1976] 3 W.W.R. 661 . 
amended section of the Code, the right to re-elect was conditional upon the consent of the Attorney General.

The Court held that Section 491 dealt only with an application to reelect after the accused had been committed to stand trial. The Court also held that where the accused desires to re-elect before committal, he has the right recognized by Cooper to do so. It is noteworthy that the effect of the Appellate ruling in MacRitchie, then, was to extend the principle in Cooper so as to recognize the right to re-elect prior to committal even if the plea to be entered was not guilty. In addition, it appeared to be immaterial whether or not the consent of the Crown was obtained.

The decision which threw into doubt the whole question of jurisdiction to allow re-election was rendered shortly after MacRitchie. ${ }^{12}$ The Supreme Court of Canada decision in Doyle v. The Queen ${ }^{13}$ however, did not concern an application for re-election. At first instance, the magistrate had granted an adjournment of a criminal proceeding for a period of four months without having put the accused to his election. Doyle sought a Writ of Mandamus discharging him from his recognizance on the ground that the magistrate had exceeded his jurisdiction in granting an adjournment of the proceedings without the consent of the accused.

The Chief Justice of Newfoundland denied the application on the ground that the magistrate had inherent jurisdiction to grant the adjournment. On appeal, the Supreme Court of Newfoundland declined to grant the order on the basis that the magistrate had not exceeded his jurisdiction. The Supreme Court of Canada allowed the appeal and ordered the issuance of the Writ of Mandamus. It was argued by the Appellant that the power of the magistrate was circumscribed by the procedural provisions of subsection 465(1) of the Criminal Code.

In the reasons for the judgment delivered by Mr. Justice Ritchie on behalf of a nine man bench, the action of the magistrate in light of subsections $465(1)$ and 463 was considered and it was held that the magistrate exceeded his jurisdiction.

In a passage to be frequently quoted by various lower Courts, Mr. Justice Ritchie said: ${ }^{14}$

Whatever inherent powers may be possessed by a superior Court judge in controlling the process of his own Court, it is my opinion that the powers and functions of a magistrate acting under the Criminal Code are circumseribed by the provisions of that statute and must be found to have been thereby conferred either expressly or by necessary implication. ... I take the view that the careful and detailed procedural directions contained in the Code are of necessity exhaustive, and as I have indicated, I regard the powers of a magistrate or justice acting under the Criminal Code as entirely statutory.

The effect of these comments was not felt initially by magistrates concerned with applications for re-election for trial by magistrate either before or during preliminary inquiries. Indeed, the Appellate Division of the Supreme Court of Alberta had occasion to reconsider the issue four months after the decision in Doyle was rendered. In R. v.Broder, Flaa and Johnston ${ }^{15}$ the accused applied to re-elect during a preliminary inquiry after the Crown had closed its case. The Crown opposed the application,

12. Id.

13. (1976) 68 D.L.R. (3d) 270,35 C.R.N.S. 1, 29 C.C.C. (2d) 177.

14. Id at 6-7.

15. (1976) 32 C.C.C. (2d) 55, (1976) W.W.D. 183. 
but the magistrate allowed the re-election and pleas of not guilty were entered. The Crown asked the judge to disqualify himself and fix a new trial date. The Court declined to do so and directed that the evidence led at the preliminary inquiry apply to the trial. The accused were acquitted. The Crown appealed on the ground that the provincial judge had no jurisdiction to allow a re-election without the consent of the Crown. In dismissing the appeal, Mr. Justice McDermid, speaking for himself, Chief Justice McGillivray, and Mr. Justice Morrow, reviewed the earlier cases and concluded that the jurisdiction of a magistrate to allow a re-election before committal for trial did not depend on the consent of the Crown. The Court in Broder considered its earlier decision in $S c o w n^{16}$ and decided it was now overruled by Cooper. ${ }^{17}$ In reviewing the reasons for the majority judgment in Cooper, the Court concluded that the fact that a guilty plea was to be entered upon the re-election was not relevant to the ruling arrived at by the Ontario Court of Appeal. The Court also cited the decision of MacRitchie $e^{18}$ with approval, and commented that the fact that an application for re-election is made before any evidence is led at a preliminary inquiry is not relevant to the jurisdictional issue under consideration. It should be noted that the decision in Doyle was not mentioned by the Alberta Supreme Court Appellate Division in Broder.

While the ruling in Broder was based upon the principle laid down in Cooper, it is interesting to note the factual differences between these two cases. Although both concerned an application for re-election during a preliminary inquiry, in Broder the accused pleaded not guilty upon reelection, the Crown did not consent to the application, and the Court acquitted upon a consideration of the evidence led at the preliminary inquiry. This ruling, although decided according to the authorities, places the Crown in an extremely difficult position where re-election is sought and granted during a preliminary inquiry. This difficulty was aptly illustrated in the Manitoba case of $R$. v. Atkinson. ${ }^{19}$ There the accused was charged with possession of a narcotic for the purpose of trafficking. He elected trial by judge alone and proceeded to preliminary inquiry. The Crown tendered into evidence a certificate of analysis. The accused objected to its admission into evidence on the ground that he had not been given reasonable notice of the Crown's intention to lead such evidence. After the objection of the defence was overruled on the ground that notice is not required at preliminary inquiry, the accused applied to reelect trial by magistrate. The application was granted over the Crown's objection and the Court then refused to admit the certificate on the basis that reasonable notice had not been given. The charge was then dismissed.

On appeal, the Crown argued that the provincial judge had no jurisdiction to do what he had done. Without dealing with the submission, the Chief Justice speaking for himself, Guy, Monnin, Hall and Matas JJ.A. said simply that the order ought to be set aside as the ruling was manifestly unfair to the Crown. However, on further appeal, ${ }^{20}$ the Supreme Court of Canada allowed the appeal, set aside the decision of the Court of

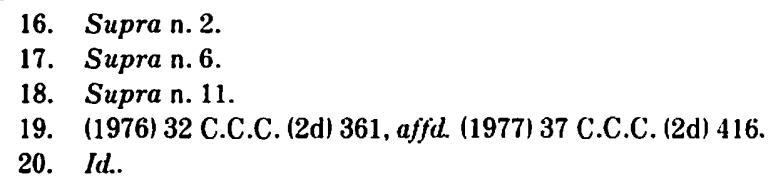


Appeal and the acquittal by the magistrate on the basis that the accused did not enter a plea after having been permitted to re-elect trial by magistrate. The Court did not refer to its earlier decision in Doyle, but by implication, appears to have held that the magistrate had the jurisdiction to allow the application to re-elect during the course of the preliminary inquiry.

The question of the right to re-elect was not considered expressly in light of Doyle until some two years after the Supreme Court of Canada rendered that decision. In $R$. v. Gray, ${ }^{21}$ the accused, after his election of trial by judge and jury, was remanded for eight days before prelininary inquiry. He was brought before a magistrate six days later at his request to apply for re-election for trial by magistrate. He then entered a plea of guilty. On appeal, his counsel argued that the decision in Doyle overruled the cases of Cross, MacRitchie, Cooper and Broder.

The unanimous view of the British Columbia Court of Appeal was that the line of cases aforementioned stood for the proposition that Sections 491 and 492 of the Criminal Code with respect to re-election were mandatory where applicable, but that before committal for trial a magistrate possessed the discretion to allow a re-election. Such procedure was not prohibited by the Code and was a matter within the discretion of the magistrate.

Dealing with the effect of Doyle upon that issue, Bull J.A. said:22

In my respectful opinion that language [at [1977] 1 S.C.R. 597 at 602] was obiter dicta and that Ritchie J. thereby did not intend to deny inferior trial courts the power to cure, or act on deficiencies in, or matters not covered by the Code. I cannot conceive of an intent to determine that when there is a silence in the Code, a Court can do nothing, however reasonable or how much reflecting common sense. The language. I think, must be read in the light of the very serious situation that was apparent in the Doyle case. What was clear from that decision was that the magistrate deliberately violated a section of the Code by adjourning for four months when (at that stage of the proceedings) he could not so do in excess of eight days, and applied another section which by its terms had no application...".

"I am unable to conclude that the decision of the Supreme Court of Canada in Doyle has had the effect of overruling Cooper, MacRitchie, Broder et ah or Cross.... The magistrate here had not flow $n$ in the face of provisions of the Code as had happened in Doyle, but having carried out a mandatory requirement merely permitted an accused at his own wish to change his election so properly given to him, and before he, the magistrate, lost his jurisdiction by a committal for trial and before another mandatory provision became applicable.

The jurisdiction of a magistrate to permit re-election during a preliminary inquiry would appear to have been clearly established. However, the subsequent decision rendered by the Alberta Court of Appeal in Davies ${ }^{23}$ now places the right of the accused to re-elect before committal very much in doubt.

The facts in that case were that Davies applied to re-elect trial by magistrate during a preliminary inquiry. The magistrate ruled that by the authority in Doyle he was without jurisdiction to grant such an application. The accused applied for certiorari or alternatively, mandamus, but was denied. On appeal, Clement J.A., Shannon J. ad hoc concurring, (Prowse J.A. dissenting) ruled that the magistrate had no jurisdiction to hear an application for re-election before a committal for trial.

21. (1977) 38 C.C.C. (2d) 292.

22. Id. at 295 .

23. [1979] 6 W.W.R. 1, 16 A.R. 426. 
The weight of authority was very strongly in favour of the existence of a magistrate's power to permit a re-election at the time the issue was argued in Davies. It was apparent that the Criminal Code was silent on the issue and the judicial interpretation was that the view that the right existed by necessary implication accorded with the legislative intent behind the statutory provisions.

\section{ANALYSIS OF THE MAJORITY JUDGMENT IN DAVIES}

Clement J.A. begins his analysis of the case authority with the early Alberta Appellate Division decision in Scown. He adds to this case five subsequent decisions to support his conclusion that a magistrate has no jurisdiction to allow a re-election before committal. The cases which he cites to support his view are: $R$. v. Siniaski ${ }^{24} R$. v. Hunter and McInroy, ${ }^{25}$ $R$. v. Doyle, ${ }^{28} R$. v. Poitras,${ }^{27}$ and $R$. v. Bubley ${ }^{28}$

It will be recalled that in $S c o w n^{29}$ the Alberta Appellate Division ruled that a magistrate had no jurisdiction to allow a re-election during a preliminary inquiry. That Court later decided that Scown had been overruled by the Supreme Court of Canada decision in Cooper. However, Clement J.A. in Davies decided that the Doyle decision must affect the authority of Cooper and therefore Scown could no longer be treated as having been overruled.

As additional support for the validity of Scown, Clement J.A. cites two Saskatchewan Court of Appeal decisions. The first, Siniaski, was rendered in 1966 prior to Cooper. The Court concluded that a magistrate had no jurisdiction to permit a re-election on the basis that there was no express statutory provision for such an application. Neither Scown nor any other authority was cited in support of this conclusion.

The second Saskatchewan decision referred to by Clement J.A. was Hunter and McInroy ${ }^{30}$ In its reasons for judgment, the Court referred to Scown but stated that it did not necessarily adopt in full the reasoning therein. The Court concluded that since, on the facts before it, no application had been made to apply the evidence from the preliminary inquiry to the trial, the conviction would have to be quashed. Although Hunter and McInroy was rendered in 1978, no reference was made by the Court to any decisions concerning the right to re-elect before committal which had been rendered subsequent to Scown. The Saskatchewan authorities do not lend particularly strong support to the view that the Scown case should be preferred to that of Broder. The Siniaski case is not forceful authority because it fails to consider the question of whether jurisdiction might exist in the absence of express Code provisions; it cites no authorities and the judgment was rendered before the line of authorities stemming from the Cooper case. The difficulties with Hunter and McInroy are that the judgment does not give unqualified approval of the reasoning in Scown; it is, strictly speaking, only authority for the narrow

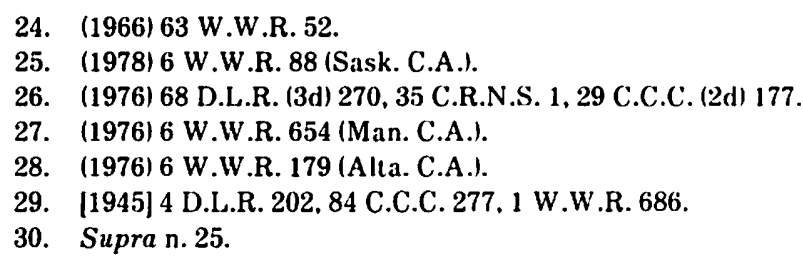


point that evidence heard on the preliminary inquiry must be expressly applied to the trial, and it fails to refer to the decisions rendered in Fairbairn, Cooper, Atkinson and Broder.

On the whole, both the Saskatchewan decisions would appear to be of doubtful value for the purpose Clement J.A. proposes, particularly in light of the Alberta ruling in Broder. Moreover, the reasons for judgment in Broder including the observation that Scown has been overruled have not been expressly disapproved in any subsequent judgment. Finally, it is submitted, with respect, that the facts of Scown, Broder and Cooper are essentially indistinguishable.

If $S$ cown is to be resurrected as Clement J.A. suggests, it would follow that he must find not only Broder but also Cooper to be incorrectly decided. Clement J.A. appears to treat Doyle as the means of so doing.

The remaining authorities cited by Clement J.A. to support the conclusion that a magistrate has no jurisdiction to allow an accused to re-elect at preliminary inquiry are $R$. v. Poitras ${ }^{31}$ and his own decision in $R$. v. Bubley. ${ }^{32}$

In Poitras, the issue was whether a magistrate had jurisdiction to hear an application during a preliminary inquiry by two accused to be "tried separately" from a third co-accused. Morse J. of the Manitoba Queen's Bench ruled that the magistrate did not have such jurisdiction. Morse J. considered that he should not ignore the comments of Ritchie J. in Doyle notwithstanding that the comments might be obiter dicta. The learned judge agreed that a provincial judge does have the authority to regulate the conduct of a preliminary inquiry by virtue of paragraph 465(1)(k) of the Criminal Code, but he held that such statutory power would not afford jurisdiction to grant the application for "separate trials", by reason that such application did not relate to a matter of procedure only.

It is submitted that the unusual nature of the application would, of itself, distinguish Poitras from Davies. Additionally, in Poitras the application was considered to be not entirely procedural and the judgment did not cite any of the decisions concerning the jurisdiction of a magistrate to grant re-elections.

In Bubley ${ }^{33}$ the issue was whether a magistrate had a broader jurisdiction than that provided for in Section 472 of the Criminal Code. Clement J.A. observed that a magistrate at a preliminary inquiry had no jurisdiction to punish for contempt of Court, except as expressly provided by statute. He then found that there was judicial authority supporting the proposition that a magistrate had no jurisdiction to hold in contempt and punish a witness who refused to answer questions without reasonable excuse. He reviewed those authorities and concluded that the power of a magistrate was defined and limited by Section 472 . Beyond that section of the Code, there was no power in a provincial judge to punish a witness for contempt of Court on a preliminary inquiry for refusal to answer questions.

From the authority in Bubley, Clement J.A. reasons in the Davies case that while a magistrate may have inherent powers indispensable to the

31. Supra n. 27.

32. Supra n. 28.

33. Id. 
proper exercise of the function assigned so long as it does not enlarge a specific statutory power, a power to hear an application to re-elect is not remotely indispensable to the function and purpose of a preliminary inquiry. Clement J.A. concludes therefore that a magistrate has no power to allow a re-election, and he cryptically comments that other times and places are appointed by the Criminal Code for that purpose.

It is submitted that the authority in Bubley may be distinguished from Davies on two bases. The first ground of distinction is the dissimilarity of the legal issues involved in each case. With respect to the issue in Bubley, a provincial judge has never had the power to punish contempt of his Court, and the lack of that jurisdiction in a magistrate has never been anything but well-settled in Canadian criminal law. The limited power that a magistrate now has to control a witness who refuses to answer questions exists by virtue of express enactment in the Criminal Code. By contrast, the issue in Davies concerns a procedural question which arises in an area clearly within the scope of the magisterial function. Another distinction between the issues involved in the above decisions is that the former case concerns the power of a magistrate to punish witnesses in a criminal proceeding, and the power, therefore, is one to restrict the freedom of individuals in respect of their presence before the Court. Davies is not concerned with a magistrate's power to restrict freedoms but to enlarge freedoms by affording the accused another chance to choose his preferred mode of trial. The second basis to distinguish Bubley from Davies is that in Bubley the Court was asked to determine the existence of a power extending beyond a power expressly provided in the statute, whereas in Davies, the Court was asked to determine whether a power exists where the statute neither expressly provides for nor prohibits such a jurisdiction. As Clement J.A. implies in his judgment in Davies, the reasoning in Bubley accords with the reasoning in Doyle, although Doyle had not been cited to the Court at the time Bubley was heard. It is suggested, however, that it does not necessarily follow from the reasons in Bubley (and Doyle) that the finding of power in a magistrate to permit a re-election is tantamount to an enlargement of a specific statutory power. Whereas in Bubley (and Doyle) the Court sets out the statutory provision to which it refers and holds that beyond that section there exists no power in a magistrate, in Davies there is no specific statutory provision in existence. Therefore, the argument of the Appellant in Davies does not purport to extend the scope of a pre-existing statutory power.

However, it must be appreciated that Clement J.A. reasons from the authorities in Bubley and Doyle to his conclusion on the stated belief that there is an express statutory provision setting out the magistrate's power to permit a re-election. If such a provision did exist, it might reasonably be concluded that the statutory provision of a magistrate was exhaustive. Unfortunately, Clement J.A. does not cite the provisions which he believes deal decisively with the issue. He may be alluding to Sections 491 and 492 as these sections speak specifically to the matters of re-election. However, other judicial authority ${ }^{34}$ has interpreted the power spoken of here as one which arises only after the accused has been committed for trial. Before these sections were enacted the jurisdiction of a

34. Cross, supra n. 9; MacRitchie, supra n. 11; Broder, supra n. 15. 
magistrate over the accused was terminated upon the committal of the accused for trial. It would appear that Parliament intended, by enacting these sections, to clothe a magistrate with jurisdiction to deal with the accused after committal where consent of the Crown had been obtained in writing. It is, therefore, unlikely that Clement J.A. is alluding to these
sections.

Alternatively, Clement J.A. may be referring to Section 465 , which deals with the powers of a justice, or a magistrate in conducting a preliminary inquiry, including the power set out in paragraph $465(1)(\mathrm{k})$ to regulate the course of the inquiry in any way that appears to him to be desirable. Yet this section does not make express reference to anything like a re-election prior to committal, nor does there appear to be anything contained in this section which contemplates an application for reelection. It is submitted that there is not, in fact, any express statutory provision dealing with re-election sufficient to support his reasoning and therefore, the decision of Clement J.A. is founded upon an erroneous premise.

To summarize, it is submitted that the cases Clement J.A. cites to support his conclusion do not support the proposition that a magistrate has no jurisdiction to permit an accused to re-elect before committal for trial. It is suggested that in the absence of strong authority conflicting with Broder, ${ }^{35}$ that decision should govern the issue. The question which remains is whether Doyle does challenge the authority in Cooper and Broder. Doyle does not address the specific question of a magistrate's jurisdiction to permit a re-election before committal. On the other hand, the conclusion in Doyle flows from the proposition that the Code provisions are exhaustive. If this proposition could be reconciled with the Cooper decision, the line of authority following Doyle could be distinguished from the legal issues involved in Davies.

The cases referred to by Clement J.A. which appear to favour the view that a magistrate may allow an accused to re-elect before committal for trial and which were distinguished are the following: $R$. v. Fairbairm ${ }^{36} R$. v. Cooper, ${ }^{37}$ R. v. MacRitchie, ${ }^{38}$ R. v. Broder, Flaa, and Johnston ${ }^{39}$ and Re Retzer and the Queen. ${ }^{40}$

It is submitted that Clement J.A. found it necessary to distinguish the above authorities in order to conclude that there was no jurisdiction in a magistrate to grant a re-election before committal. Upon close examination, however, it would appear that the distinguishing features relied upon by Clement J.A. are of no real significance.

Dealing with the above cited cases in turn, it appears that Clement J.A. is of the view that Fairbairn does not bear directly on the issue before him. He appears to find that Fairbairn is distinguishable by reason that the application there was made before the preliminary inquiry was launched. He expresses this opinion while, in the same breath, noting that the Courts in Cooper and Broder disclaimed the relevance of that factor to

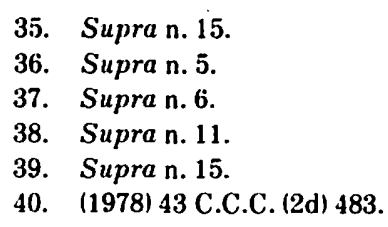


the issue of a magistrate's jurisdiction to permit a re-election before committal. On this point, Clement J.A. favours the views of Laskin J.A. (dissenting) in Cooper and Harvey C.J.C. in Scown. According to Cooper and Broder, the time of the application is only important in that it must be made before committal.

Clement J.A. makes no further comment as to the authoritativeness of Fairbairn. It is submitted with respect that he did not have sufficient regard for the weight of the unanimous ruling of the Ontario Court of Appeal deciding that a magistrate has jurisdiction to allow a re-election before committal. As such, Fairbairm, a decision of persuasive authority on all fours with the facts in Davies, should be followed unless there are good reasons to arrive at a contrary result. It is again emphasized that other courts in binding decisions have addressed the distinguishing feature raised by Clement J.A. and held it to be irrelevant to the issue.

The next decision distinguished by Clement J.A. is Cooper. Clement J.A. takes the view that Cooper may nolonger be good law by virtue of the decision in Doyle. It will be argued later that Cooper and Doyle can stand together. But Clement J.A. goes on to distinguish Cooper on another basis, that being that Cooper re-elected in order to plead guilty whereas Davies sought to re-elect and proceed to trial before the magistrate. Although he notes that Laskin J.A. considered that a guilty plea was irrelevant to the question of a magistrate's jurisdiction to allow a reelection, Clement J.A. maintains that a guilty plea would be a factor to be considered to support that jurisdiction.

It is submitted that this reasoning poses certain difficulties because the Courts have not yet effectively dealt with the consequences of a plea of not guilty following a re-election prior to or during a preliminary inquiry. The problems which arise upon a plea of not guilty therefore cloud the issue of whether there is a jurisdiction to permit a re-election. These considerations should be kept quite distinct from the determination of jurisdiction.

With respect to the power of a magistrate to permit re-election, it will be recalled that in Cooper the accused sought a speedy disposition of the case, he advised the Court of his intention to plead guilty, all parties were in agreement that such an application should be granted, and common sense suggested that the granting of such an application would accord with the legislative intent of the Code provisions and the ends of justice. These factors will not all be present every time a magistrate is asked to permit a re-election. It must be understood that these factors cannot be taken into account to determine whether jurisdiction exists. That consent will not give jurisdiction to a magistrate was a proposition approved of both by Harvey C.J.C. in Scown and by Clement J.A. in Davies. Certainly the fact that the Crown is not consenting to the application cannot be a relevant factor. A fortior $i$ the plea the accused intends to enter cannot be a factor relevant to the existence of jurisdiction. As Laskin J.A. (dissenting) in Cooper correctly points out, such a consideration begs the question because it is a matter occurring subsequent to the exercise of discretion which is based upon the very existence of jurisdiction sought to be supported by the factor of a guilty plea.

This analysis leaves the one other point raised by Clement J.A. to preclude an obligation to follow Cooper, which is the suggestion that 
Doyle overrules Cooper. This point shall be explored after the remaining cases decided prior to Doyle are discussed.

The next decision considered by Clement J.A. was MacRitchie. ${ }^{11}$ Clement J.A. considers that this decision is similar to Fairbairn, again implying that the case is distinguishable from the case before him. MacRitchie had applied to re-elect before the preliminary inquiry was launched. The unanimous decision of the British Columbia Court of Appeal was that a magistrate had jurisdiction to permit a re-election any time before committal for trial, notwithstanding opposition by the Crown. In so holding, the Court referred with approval to the British Columbia Supreme Court decision in Cross. ${ }^{42}$ Both cases involved the issue of Crown consent which may arise where a re-election is followed by a plea of not guilty. Clement J.A. does not refer to Cross at all and does not deal with MacRitchie at any length. He appears to be of the view that the decision is not of great persuasive value because it was rendered before the Supreme Court of Canada decision in Doyle. It is submitted that MacRitchie should be carefully considered and it should be noted that the Alberta Court of Appeal saw fit to follow it in its own decision in Broder.

Clement J.A. does not mention the approval of MacRitchie expressed by the Alberta Appellate Division in his discussion of Broder. He quickly dismisses this latter decision after finding it to be distinguishable by reason that in Broder the issue was merely whether the consent of the Crown is required before an application for re-election should be granted. He appears to be of the view that Broder does not consider the question of the jurisdiction of the magistrate to hear such an application. It is respectfully submitted that Clement J.A. has misinterpreted Broder. The Court in Broder held by implication that a magistrate has jurisdiction to grant a re-election, since, without such power, the Crown consent would be irrelevant. Clearly, the existence of jurisdiction is implied in Broder. Clement J.A. points out that jurisdiction to entertain an application to re-elect cannot be acquired by consent. It is submitted that the issue in Davies was squarely met by the Appellate Division in Broder and there does not appear to be any rational basis upon which the two cases can be distinguished.

In concluding his reasons for judgment, Clement J.A. holds that on the authority of Doyle, the magistrate has no jurisdiction to hear an application for re-election before committal. He concludes that Doyle overrules Cooper, and feels himself bound by Doyle for the following reasons:

1. Doyle dealt with the point in issue in Davies.

2. The Supreme Court of Canada in Doyle sat with eight members while Cooper was decided by a five member bench.

3. Doyle was decided later than Cooper.

4. Cooper merely approved the reasons of the lower court without dicussion.

The validity of Cooper in light of Doyle may now be considered. There are three submissions to be made:

1. Doyle is distinguishable from Cooper on its facts.

41. Supra n. 11.

42. Supra n. 9. 
2. The comments of Ritchie J. in Doyle relied upon by Clement J.A. are obiter dicta.

3. Doyle and Cooper can be reconciled, and therefore it is not necessary to find that Doyle overrules Cooper.

In Doyle it will be recalled that the ruling was that the magistrate failed to act in accordance with express statutory provisions respecting adjournments and elections. It was decided that a magistrate had no discretion to grant an adjournment resulting in a delay of proceedings of four months without having given the accused an election of a forum for trial. Concerning the relevant Code provisions, the Court noted that the duties of a magistrate therein prescribed were phrased in mandatory language.

$\mathrm{Mr}$. Justice Ritchie noted that the intent of the procedural provisions of the Code was to provide a speedy disposition of cases. ${ }^{43}$

In the context of those facts and the applicable statutory provisions, Justice Ritchie asserted that the procedural provisions of the Criminal Code should be taken as exhaustive of the powers of a magistrate.

Since the facts in Doyle concern only the effect of a magistrate exceeding the power under the aforementioned Code provision, it was not necessary to the decision of Ritchie J. to find that Code provisions are exhaustve generally. Therefore, his comments in this respect should be regarded as obiter dicta. It is further submitted that Ritchie J. made that general comment in relation only to Sections $463,464,465$ and 484 , which were the provisions under consideration in that case. In this light, it seems that the remarks of Ritchie J. were intended to apply to matters in respect of which the magistrate's power is specifically set out in the statute. The magistrate's power with respect to adjournments and elections are specified and are mandatory. In that situation, a magistrate cannot fail to do what the Code provides that he shall do or he loses jurisdiction.

As to the matters for which the Code does not expressly set down certain procedural steps, Mr. Justice Ritchie made one bare reference. ${ }^{44}$

... the powers and functions of a magistrate ... must be found to have been ... conferred [under ithe Criminal Code] either expressly or by necessary implication. [emphasis added]

It should be apparent from this isolated reference that Ritchie J. recognizes the existence of a discretion in a magistrate which was not expressly provided by statute. Since the facts of Doyle concerned the exercise of a discretion not only beyond the clearly prescribed statutory functions, but contrary to such provisions, there was no need for Ritchie J. to discuss further the aspect of a magistrate's discretion in the absence of express statutory provision. In light of these propositions, the reasons of Clement J.A. in holding that Doyle overrules Cooper must be examined.

First, one must question the propriety of assuming the Supreme Court of Canada might overrule one of its earlier decisions without any express mention of the case purported to be overruled, nor of the issue considered in that unmentioned case. If the Supreme Court of Canada had intended to overrule Cooper, by its decision in Doyle, it would surely have discussed Cooper and explained for example, the power of magistrates to hear applications for changes of plea from not guilty to guilty and vice versa. In

43. R. v. Doyle (1976) 35 C.R.N.S. 1 at 11 .

44. Ill. all 6 . 
fact, Ritchie J. thought that the legislative intent of the Code provisions regarding procedure was to facilitate speedy disposition of cases and this assumption appears to accord with the reasons for judgment approved by the Supreme Court of Canada in Cooper.

It is respectfully submitted that the number of members on a bench is not a basis for preferring one decision of a Court over another of its own decisions, nor is recency a basis for preference. It is suggested that the comments of Ritchie J. are dicta rather than ratio, that the decision in Cooper was on all fours with Davies and, therefore, Cooper should be taken as binding and Doyle considered distinguishable.

The last decision referred to in the majority judgment in Davies is Retzer. ${ }^{45}$ The first comment of Clement J.A. is that Retzer is similar to Fairbairn. He does not delineate the similarity and the only one apparent is that in each case the application was made before the commencement of the preliminary inquiry. In fact, Retzer is distinct from Fairbairn and all other cases in this area in a rather material respect. In Retzer, the accused had elected trial by magistrate and then elected before trial to have the trial converted to a preliminary inquiry. Such an application is on a footing entirely different from the kind of re-election under discussion, it is submitted, by reason of the express statutory provision allowing a magistrate to convert a trial to a preliminary inquiry for any reason (Criminal Code s.485). This possible implication of Section 485 was not considered in Retzer and notwithstanding the statutory power as described in Section 485, the Court held that the absence of a specific statutory provision did not preclude a provincial judge from hearing an application to withdraw an election and permitting a re-election to be made as if there has been no initial election. This ruling was based upon the authority in Cooper. Retzer holds that a magistrate has inherent jurisdiction to permit a re-election and that the exercise of such discretion is not limited to instances where in law there has been no initial election.

In summary, the decisions discussed in this section are not distinguished by Clement J.A. on any satisfactory basis and must be taken to create a strong line of authority against the proposition he has advanced. On the other hand, the decision of Doyle which Clement J.A. thought to be binding would appear to be distinguishable on its facts and on the legal issue considered.

A part from the cases discussed by Clement J.A. in his reasons for judgment in Davies, there are three recent authorities of interest to the issue at hand. These are the cases of Atkinson and Gray, which have been referred to earlier, and the decision of $R$. v. Matheson ${ }^{46}$ handed down by the Manitoba Court of Appeal. The salient features of Atkinson are that the Supreme Court of Canada decision implicitly supports the validity of the principle enunciated in Cooper and, in so doing, does not contain any reference to the Court's earlier decision in Doyle. Gray and Matheson are decisions which both squarely address the question of whether Doyle affects the authority in Cooper. In a well-reasoned discussion, the British Columbia Court of Appeal in Gray concludes that Doyle is distinguishable from Cooper and that both are valid. In Matheson, the Manitoba Court reaches similar conclusions. These decisions would appear to add to the

45. Supra n. 40.

46. [1979] 6 W.W.R. 738. 
substantial weight of authority favoring the finding of jurisdiction in a magistrate to permit re-elections before committal for trial.

It is respectfully submitted that the dissenting opinion of Prowse J. A. in Davies is more in line with the weight of authority. The issue as stated by Prowse J.A. is whether Broder has been overruled by the Supreme Court of Canada in Doyle, and in particular by the statement of Ritchie J. to the effect that the procedural directions of the Code are exhaustive. Prowse J.A. notes that the facts in $A$ tkinson are similar to those in $B$ roder and he finds the conclusion of the Supreme Court of Canada in Atkinson to be completely inconsistent with the proposition that the right of reelection has been determined finally by Doyle. He therefore finds himself bound by Broder.

\section{CONCLUSION}

The foregoing analysis demonstrates that there is little judicial support for the view of Clement J.A. that a magistrate has no authority to permit a re-election during a preliminary inquiry. It has also been demonstrated that the reasoning in the judgment of Clement J.A. has not been based on well-substantiated premises. It is therefore respectfully submitted that Davies was decided per incuriam, that the judgment of Clement J.A. is incorrect and that the earlier decision of the Alberta Court of Appeal in Broder should be preferred. Accordingly, it is submitted that the rule should be that a magistrate has jurisdiction to hear an application for re-election prior to committal for trial. Although there are no express Criminal Code provisions excluding or providing for such a jurisdiction, it should be accepted that such a power exists by necessary implication.

Once it is accepted that a magistrate does have jurisdiction to hear an application for re-election before committal for trial, consideration must be given to the factors affecting the granting or denying of such an application. It is at this juncture that factors such as the plea intended to be entered, the time of the application, and the circumstances of the Crown's position should be assessed properly by the magistrate.

It will be recalled that the accused in Cooper applied to re-elect in order to plead guilty. Although subsequent cases dealt with the jurisdictional question where the accused re-elected without the intention of pleading guilty, none of these latter cases considered the implications of a not guilty plea from the Crown point of view.

The Crown in practice rarely opposes an application for re-election where the accused represents to the Court that he intends to enter a plea of guilty. In such a situation, the parties are consenting to the application, and all the interests cited in the Cooper judgment would appear to be served. In such circumstances, there would be no reason for the magistrate to deny the application.

However, where the accused seeks to re-elect in order that he may be tried by a magistrate, and thus intends to enter a plea of not guilty, the application will probably be opposed by the Crown. If the Crown appears for a preliminary inquiry, it may have intended to call evidence sufficient only to secure a committal for trial. The Crown may be taken by surprise by the application to proceed immediately to trial. If the Crown opposes the application on the basis of surprise, the Court, if satisfied that the accused is entitled to re-elect, should be receptive to an application by the Crown for an adjournment. 
Where the application is granted in mid-preliminary and the accused enters a plea of not guilty, the magistrate should bear in mind the objections of Harvey C.J.C. in Scown, which are pertinent in this context. These objections include the fact that the magistrate has heard some evidence led at the preliminary inquiry, and has applied his mind only to the sufficiency of that evidence. It is not fair to the magistrate to require him, in the middle of the proceedings, to reconsider evidence already heard. Second, the appearance of unfairness to the Crown may arise, as pointed out by Freedman C.J. in his reasons for judgment in Atkinson. ${ }^{47}$ In these circumstances, the magistrate should be most reluctant to allow an accused to convert the preliminary inquiry to a trial over the Crown objection. Where however, he does so, he should not permit the evidence previously led at the preliminary inquiry to be applied without the consent of both parties; he should, in fairness to the Crown, adjourn the matter and fix a new trial date.

It is submitted that the interests of both parties and the interests of justice would be best served by considering the question of re-election in the context of the above factors rather than resorting to the rigid formalism of denying the right of re-election altogether.

47. Supra n. 19. 